\title{
Reproduction in Weasels Mustela nivalis in Poland
}

\author{
ROZROD ŁASIC MUSTELA NIVALIS NA TERENIE POLSKI
}

\author{
Bogumiła JĘDRZEJEWSKA
}

\begin{abstract}
Jędrzejewska B., 1987: Reproduction in weasels Mustela nivalis in Poland. Acta theriol., 32, 30: 494-496 [With 1 Table]

Eighteen female weasels Mustela nivalis Linnaeus, 1766, in breeding condition were caught in different parts of Poland from 1962 to 1986. All were examined macroscopically. Pregnancies occurred from April to September. Lactating females were caught from May to September. Young would thus leave their nests from May/June to late October. Two females were found to be pregnant and lactating simultaneously. No signs of reproduction were found in winter.
\end{abstract}

[Mammals Research Institute, Polish Academy of Sciences, 17-230 Bialowieża, Poland]

\section{INTRODUCTION}

The reproduction cycle of female weasels Mustela nivalis Linnaeus, 1766 , is a much debated subject for two reasons. First, it is difficult to obtain field data because pregnant and lactating females are extremely trap-shy (King, 1980). Second, reproduction in weasels highly depends on rodent abundance (Erlinge, 1975). The scarcity of field data has partially been compensated for by many successfull attempts to breed weasels in captivity (East \& Lockie, 1964; Heidt et al., 1968; Ternovski, 1977). A great deal of the information obtained in this way is, however, of limited usefulness with regard to natural habitats. With a gestation period of 35 days (the shortest accurately determined in Carnivora) and lactation of 1.5 months (Ternovski, 1977), weasels may produce two litters per year. This was determined in enclosure or cage breeding (Heidt et al., 1968). During years with low rodent densities weasels do not breed (Erlinge, 1975). The length of the reproductive season is thought to be highly variable throughout Europe, Asia and North America (Hall, 1951; Heptner et al., 1967; King, 1980).

This paper reports on wild-trapped, reproductively active females and not fully grown young caught at different localities in Poland. 


\section{MATERIAL}

Twenty-one specimens were analyzed: 18 females in breeding condition and 3 not fully grown young. Sixteen weasels come from the collection of the Mammals Research Institute, Polish Academy of Sciences, in Białowieża. The whole collection consists of over 150 weasels that were casually trapped in different rodent traps during field studies conducted in different parts of Poland from 1946 to 1986. The collection represents all seasons of the year. Five weasels came from the collection of Dr. J. Goszczyński, and were found in the buzzards' (Buteo buteo) nests at Turew, Wielkopolska in 1969-1971. All specimens were sectioned and examined macroscopically.

Table 1

Data on reproduction in weasels Mustela nivalis in Poland.

\begin{tabular}{|c|c|c|c|c|}
\hline \multicolumn{3}{|c|}{$\begin{array}{l}\text { Date } \\
\text { of capture }\end{array}$} & $\begin{array}{l}\text { No. of } \\
\text { embryos }\end{array}$ & Notes \\
\hline & \multicolumn{4}{|c|}{ Pregnancies } \\
\hline 29 & April & 1971 & 6 & \multirow{7}{*}{ embryos $25 \mathrm{~mm}$ long } \\
\hline 19 & May & 1969 & & \\
\hline 20 & May & 1969 & 4 & \\
\hline & June & 1969 & 5 & \\
\hline & June & 1969 & 4 & \\
\hline 28 & June & 1971 & 8 & \\
\hline & July & 1966 & $\begin{array}{l}5 \\
4\end{array}$ & \\
\hline 8 & July & 1986 & $\begin{array}{l}4 \\
7\end{array}$ & \multirow{4}{*}{$\begin{array}{l}\text { live-trapped, on August } 2 \\
\text { delivered } 7 \text { young in enclosure } \\
\text { embryos } 11 \mathrm{~mm} \text { long } \\
4 \text { embryos almost completely } \\
\text { resorbed, } 2 \text { alive } 15 \mathrm{~mm} \text { long }\end{array}$} \\
\hline 16 & July & 1986 & 7 & \\
\hline 19 & July & 1970 & 6 & \\
\hline 21 & July & 1970 & 6 & \\
\hline & July & $1962^{1}$ & 5 & \multirow{2}{*}{$\begin{array}{l}\text { lactating } \\
\text { lactating }\end{array}$} \\
\hline & $\begin{array}{l}\text { Aug } \\
\text { Sept }\end{array}$ & $1962^{2}$ & $\begin{array}{l}4 \\
4\end{array}$ & \\
\hline \multicolumn{5}{|c|}{ Lactations } \\
\hline 28 & May & 1971 & \multirow{5}{*}{\multicolumn{2}{|c|}{ milk in 2 pairs of teats }} \\
\hline 18 & July & 1964 & & \\
\hline 21 & July & 1963 & & \\
\hline $\begin{array}{r}28 \\
2\end{array}$ & $\begin{array}{l}\text { July } \\
\text { Aug }\end{array}$ & $\begin{array}{l}1962^{1} \\
1962^{2}\end{array}$ & & \\
\hline & Aug & 1966 & & \\
\hline \multicolumn{5}{|c|}{ Placental scars } \\
\hline 29 & Sept. & 1970 & \multirow{4}{*}{\multicolumn{2}{|c|}{$\begin{array}{l}\text { 2 scars (L1R1) } \\
\text { Not fully grown young } \\
\text { body length } 115 \mathrm{~mm} \text {, body } \\
\text { mass } 32 \mathrm{~g} \\
126 \mathrm{~mm}, 19.3 \mathrm{~g} \\
\text { body mass } 25.2 \mathrm{~g} \text {, skull soft, } \\
\text { not fully ossified }\end{array}$}} \\
\hline 28 & July & 1971 & & \\
\hline & June & 1971 & & \\
\hline 14 & Oct & 1986 & & \\
\hline
\end{tabular}

${ }_{1,2}$ denote the same specimens recorded under different subtitles. 


\section{RESULTS AND DISCUSSION}

Complete data are presented in Table 1. No signs of reproduction were found in winter. The definite anoestrus in winter was also reported for British weasels (King, 1980). In our material the first pregnancies were noted in April and occurred onwards until the end of September. Lactating females were found from May to September.

Two females were pregnant and at the same time showed evidence of lactation (in July/August). The author concludes that these two were expecting their second litters. A second pregnancy in weasels may start with conception during post partum oestrus (Heidt et al., 1968). Two litters per season have not been seen in European weasels so far, but were reported in American M. nivalis (Heidt, 1970). Heptner et al. (1967) found two litters per year in the Asiatic part of the USSR. In the Baikal Lake region lactating and simultaneously pregnant females were caught in late June and late July. In Kazakhstan such females were caught in May.

The young, not fully grown animals most probably had left the nests prematurely. The dates of their emergence fall within the reproduction period, already determined by data on pregnant and lactating females.

The whole breeding season from mating (in April) to the time when the latest young leave their nests (in October) proved to be very extensive in Poland. It may last up to seven months which is longer that in the British Isles (King, 1980) where winters are considerably milder. These conclusions, however, may result from the small number of animals that both King and the author had.

The number of embryos per female ranged from 4 to 8 , with 4 as a median and the mean, $5.2(\mathrm{SD}=1.25)$. The number of live embryos arveraged $4.9(\mathrm{SD}=1.49)$. This is less than the 5.6 reported by King (1980) and 6.4 obtained by Deansley (1944; cited after King, 1980) for British weasels.

Data pooled for many years show a potential situation rather than a typical one, and may correspond to good years with abundant prey.

A cknowiecigmen:s: My thanks are due to Dr. J. Goszczyński for his kind permission to use his material.

\section{REFERENCES}

East K. \& Lockie J. D., 1968: Observations on a family of weasels (Mustela nivalis) bred in captivity. Proc. Zool. Soc. Lond., 143: 359-363. - Erlinge S., 1974: Distribution, territoriality and numbers of the weasel Mustela nivalis in relation tœ prey abundance. Oikos, 25: 308-324. - Hall E. R., 1951: American weasels. Univ. Kransas Publ., Mus. Nat. Hist., 4: 1-466. - Heidt G. A., 1970: The least weasel iviusteia ntvatts L. Developmental biology in comparison with other North American MIustela. Mich. State Univ., Publ. Mus. (Biol. Ser.), 4: 227-282. - Heidt G. A., P'etersen M. K. \& Kirkland G. L., Jr., 1968: Mating behavior and development of leeast weasels (Mustela nivalis) in captivity. J. Mammal., 49: 413-419. - Heptner 
W. G., Naumov N. P., Yurgenson P. B., Sludskij A. A., Čirkova A. F. \& Bannikov G. A., 1967: [Mammals of the USSR]. Izd. Wyšsaja Škola. Vol. 2: 1-1004. Moskva. [In Russian]. - King C. M., 1980: Population biology of the weasel Mustela nivalis on British game estates. Holarctic Ecol., 3: 160-168. - Ternovski D. V., 1977: [Biology of mustelids]. Izd. Nauka, Novosibirsk. [In Russian].

Received 15 May 1987, Accepted 6 June 1987. 